\title{
Primatology in southern Brazil: a transdisciplinary approach to the conservation of the brown-howler-monkey Alouatta guariba clamitans (Primates, Atelidae)
}

\author{
Leandro Jerusalinsky ${ }^{1}$, Fernanda Zimmermann Teixeira ${ }^{2}$, Luisa Xavier Lokschin ${ }^{3}$, \\ André Alonso², Márcia Maria de Assis Jardim4, Juliane Nunes Hallal Cabral, \\ Rodrigo Cambará Printes ${ }^{5} \&$ Gerson Buss ${ }^{2}$
}

1. Instituto Chico Mendes de Conservação da Biodiversidade, Centro Nacional de Pesquisa e Conservação de Primatas Brasileiros, Praça Anthenor Navarro, 05, 58010-480 João Pessoa, PB, Brazil. (ljerusalinsky@yahoo.com.br)

2. Programa de Pós-Graduação em Ecologia, Universidade Federal do Rio Grande do Sul, Av. Bento Gonçalves, 9500, Setor 4, Prédio 43422, sala 102, Caixa Postal 15007, 91501-970 Porto Alegre, RS, Brazil.

3. Programa de Pós-Graduação em Ecologia, Universidade Estadual de Campinas, Caixa Postal 6109, 13083-970 Campinas, SP, Brazil

4. Laboratório de Ecologia de Vertebrados, Universidade Federal de Pelotas, Campus Universitário Capão do Leão, s/nº, 96010-900, Pelotas, RS, Brazil.

5. Universidade Estadual do Rio Grande do Sul, Rua Assis Brasil, 842, 95400-000, São Francisco de Paula, RS, Brazil.

\begin{abstract}
Human interventions in natural environments are the main cause of biodiversity loss worldwide. The situation is not different in southern Brazil, home of five primate species. Although some earlier studies exist, studies on the primates of this region began to be consistently carried out in the 1980 s and have continued since then. In addition to important initiatives to study and protect the highly endangered Leontopithecus caissara Lorrini \& Persson, 1990 and Brachyteles arachnoides E. Geoffroy, 1806, other species, including locally threatened ones, have been the focus of research, management, and protection initiatives. Since 1993, the urban monkeys program (PMU, Programa Macacos Urbanos) has surveyed the distribution and assessed threats to populations of Alouatto guariba clamitans (Cabrera, 1940) in Porto Alegre and vicinity. PMU has developed conservation strategies on four fronts: (1) scientific research on biology and ecology, providing basic knowledge to support all other activities of the group; (2) conservation education, which emphasizes educational presentations and long-term projects in schools near howler populations, based on the flagship species approach; (3) management, analyzing conflicts involving howlers and human communities, focusing on mitigating these problems and on appropriate relocation of injured or at-risk individuals; and finally, (4) Public Policies aimed at reducing and/or preventing the impact of urban expansion, contributing to create protected areas and to strengthen environmental laws. These different approaches have contributed to protect howler monkey populations over the short term, indicating that working collectively and acting on diversified and interrelated fronts are essential to achieve conservation goals. The synergistic results of these approaches and their relationship to the prospects for primatology in southern Brazil are presented in this review.
\end{abstract}

KEYWORDS. Conservation biology, environmental education, brown howler monkey, public policies, urban monkeys program.

RESUMO. Primatologia no sul do Brasil: uma abordagem transdisciplinar para a conservação do bugio-ruivo Alouatta guariba clamitans (Primates, Atelidae) na região de Porto Alegre, Brasil. Intervenções humanas nos ambientes naturais são a principal causa da perda de biodiversidade global. Essa situação não é diferente no sul do Brasil, onde vivem cinco espécies nativas de primatas. Embora existam algumas pesquisas anteriores, estudos sobre primatas nessa região começaram a ser desenvolvidos consistentemente no início da década de 1980 e continuaram sendo produzidos desde então. Além de importante iniciativas para pesquisar e conservar as espécies altamente ameaçadas Leontopithecus caissara Lorrini \& Persson, 1990 e Brachyteles arachnoides E. Geoffroy, 1806, outras espécies, incluindo algumas localmente ameaçadas, têm sido foco de pesquisas, manejo, e iniciativas de conservação. Desde 1993, o Programa Macacos Urbanos (PMU) tem pesquisado a distribuição e avaliado as ameaças às populações de Alouatta guariba clamitans (Cabrera, 1940) em Porto Alegre e arredores. O PMU tem desenvolvido estratégias de conservação em quatro frentes de trabalho: (1) pesquisa científica em biologia e ecologia, gerando conhecimento básico para apoiar as outras iniciativas do grupo; (2) educação para conservação, que enfatiza ações educativas e projetos de longo-prazo em escolas localizadas próximas às populações do bugio-ruivo, baseados na abordagem de espécie-bandeira; (3) manejo, analisando conflitos que envolvam bugios e comunidades humanas, focando na mitigação desses problemas e na apropriada destinação dos animais machucados ou em risco; e (4) a frente de trabalho de Políticas Públicas, que visa reduzir e/ou prevenir os impactos da expansão urbana, contribuindo para criar áreas protegidas e fortalecer a legislação ambiental. Estas diferentes abordagens têm contribuído para a conservação das populações do bugio-ruivo em curto prazo, indicando que trabalhos desenvolvidos coletivamente e a atuação em frentes de trabalho interrelacionadas e diversificadas pode ser essencial para atingir as metas de conservação. Os resultados sinergéticos dessas abordagens e sua relação com a primatologia na região sul do Brasil são apresentados neste trabalho.

PALAVRAS-CHAVE. Biologia da Conservação, educação ambiental, bugio-ruivo, políticas públicas, Programa Macacos Urbanos.

\section{Primate Species in Southern Brazil}

The southern region of Brazil, which encompasses the states of Paraná, Santa Catarina, and Rio Grande do Sul, contains large areas of Atlantic forest ecosystems. The forested areas are inhabited by five native primates (Prates et al., 1994; ChiARello, 2003; Passos et al. 2007; Melo et al., 2009): the blackand-gold howler monkey -Alouatta caraya Humboldt,
1812, the brown howler monkey - Alouatta guariba clamitans (Cabrera, 1940), the southern muriqui Brachyteles arachnoides Geoffroy, 1806, the black capuchin monkey - Cebus nigritus Goldfuss, 1809, and the black-faced lion tamarin - Leontophitecus caissara Lorini \& Persson, 1990. The distribution of A. caraya extends to the Cerrado (central Brazil savanna) and its riparian forests; the other four species are endemic to the Atlantic forest. 
This relatively low primate species richness compared to other Brazilian regions such as the southeast and the north is probably associated with the distinct seasonality at these higher latitudes (PERES \& J ANSON, 1999). Seasonality in southern Brazil offers particular conditions for primatological research, which has generated, for example, interesting results on biogeography (BICCA-MARQUES, 1990; PRINTES et al., 2001; Codenotti et al., 2002; Koenler et al., 2005; AgUiar et al., 2007) and on behavioral and ecological plasticity in these extreme climates (PRATES et al., 1990b; JARDIM \& Oliveira, 2000; Miranda et al., 2004.; MirANDA et al., 2005).

These primate species are categorized as threatened or endangered in global, national, or regional red lists (Tab. I). To confront the challenge of conserving these species, the severe habitat fragmentation and its potential and observed impacts on primate populations have focused the attention of primatologists in southern Brazil (Printes, 1999; Ribeiro \& Bicca-Marques, 2005; Aguiar et al., 2007; Silva \& CodenOTTI, 2007).

Here we present an overview of primate studies in southern Brazil. As a study case of diversified efforts for primate conservation in this region, we report the transdisciplinary approach and the main results of the four working fronts (scientific research, conservation education, management, and public policies) of the Programa Macacos Urbanos (PMU, Urban Monkeys Program, created in 1993 as an undergraduate student project in the Department of Zoology of the Universidade Federal do Rio Grande do Sul) towards the maintenance of brown-howler monkey populations in Porto Alegre and vicinity, in the southernmost state of Brazil.

\section{An historical overview of primatology in southern Brazil: gaps and priorities}

A workshop during the XXVII Brazilian Congress of Zoology evaluated the development and current situation of primatology in each of the five Brazilian geographic regions, reviewing scientific journals published since 1969, and the series A Primatologia no Brasil (Melo et al., 2009). Although some of these papers predate 1980, the effective development of primatology in southern Brazil began in the 1980s in Rio Grande do Sul, and in the 1990s in Santa Catarina and Paraná. The increasing number of scientific publications in recent years, especially those reporting results from research in Paraná and Rio Grande do Sul, clearly reflects the recent expansion of primatology in this region.
Studies of the widespread Alouatta Lacépède, 1799 species were concentrated in a few municipalities, and $A$. guariba clamitans was most often studied. Since the beginnings of primatology in southern Brazil, several studies have examined behavior and ecology in A. $g$. clamitans (Prates et al., 1990a; JARDIM \& Oliveira, 2000; MiRANDA et al., 2004; MiRANDA et al., 2005) and Alouatta caraya (Bicca-Marques, 1992; Bicca-Marques \& Calegaro-Marques, 1993; Calegaro-Marques \& BiccaMARQues, 1993). In the past decade, primatologists have given increasing attention to the severe habitat fragmentation and the ways in which it impacts the primate populations (Printes, 1999; Ribeiro \& BicCA-Marques, 2005; Aguiar et al., 2007; Silva \& Codenotti, 2007). One focus of these studies has been conflicts resulting from the proximity of human and non-human primate populations near urban areas (PRINTES, 1999; LOKSCHIN $e t$ al., 2007).

Since 1990 , but mainly in the 2000s, research on primate biogeography in southern Brazil has yielded interesting information, including the discovery of the austral limit for all Neotropical primates, represented by a population of A. g. clamitans (PRINTES et al., 2001), but also the southernmost boundaries for the other atelids, Brachyteles arachnoides (KOEHLER et al., 2002) and A. caraya (BICCA-MARQUES, 1990). Other notable reports on this subject were the description of sympatric areas and potential hybridization zones involving A. caraya and $A$. g. clamitans in Paraná (Aguiar et al., 2007; AgUiar et al., 2008) and Rio Grande do Sul (BICCA-MARQuES et al., 2008; Fortes \& BiCCA-MARques, 2008).

According to Melo et al. (2009), research priorities in southern Brazil include: a) studies on biogeography, mainly in Santa Catarina; b) studies on population ecology, including demography, population dynamics, and estimates of population sizes; c) analyses of the main threats, to more effectively guide conservationist management efforts; d) evaluation and control of the potential impacts of the introduced species, primarily Callithrix Erxleben, 1777 in Santa Catarina; and e) studies on the impact of yellow fever on A. g. clamitans and especially A. caraya populations in Rio Grande do Sul.

\section{Primatology working groups in southern Brazil}

The southern region plays an important role in Brazilian primatology, due to its history and potential in the training of new researchers and managers. Primatologists trained in southern Brazil have participated

Table I. Primate species occurring in southern Brazil, the states where they occur, and their conservation status $\left({ }^{1}\right.$, states of the southern region of Brazil, where the species occur: PR, Paraná; RS, Rio Grande do Sul; SC, Santa Catarina; ${ }^{2}$, following the IUCN criteria (IUCN, 2001): CR, Critically endangered; EN, Endangered; VU, Vulnerable; NT, Near threatened; LC; Least concern; ${ }^{3}$, IUCN, 2010; ${ }^{4}$, Brasil, 2003, Machado et al., 2005; ${ }^{5}$, refers to regional lists of threatened species published by Brazilian states: PR (Paraná, 2004), RS (Rio Grande do Sul, 2002); Santa Catarina does not yet have an official list).

\begin{tabular}{lccc}
\hline & & \multicolumn{2}{c}{ Conservation $^{\text {status }}{ }^{2}$} \\
Species/Subspecies & State $^{1}$ & Global $^{3}$ & National $^{4}$ \\
\hline Alouatta caraya Humboldt, 1812 & RS, SC, PR & LC & Regional \\
Alouatta guariba clamitans (Cabrera, 1940) & RS, SC, PR & LC & N T \\
$\begin{array}{l}\text { Brachyteles arachnoides Geoffroy, 1806 } \\
\text { Cebus nigritus Goldfuss, 1809 }\end{array}$ & PR & EN & EN (PR, RS) \\
Leontopithecus caissara Lorini \& Persson, 1990 & RS, SC, PR & N T & NT \\
\hline
\end{tabular}


in or are developing field studies in other states. Several of them are working in some of the major research and environmental institutions in the country, in some cases in managerial positions. Primate research groups are currently established in each state of the southern region. In Paraná, the Instituto de Pesquisas Ecológicas has carried out scientific research and education projects for the conservation of Leontopithecus caissara since 1995 (e.g., Padua \& Prado, 1996; Prado \& Valladares-Padua, 2004). Groups from the Universidade Federal do Paraná and the Universidade Estadual de Londrina have principally focused on Alouatta species in ecological (e.g., Miranda et al., 2004) and epidemiological (e.g., GARCIA et al., 2005) research in the last decade. In Santa Catarina, the Projeto Bugio (howler monkey project), a cooperative project of the Fundação Universidade Regional de Blumenau and the municipality of Indaial, has worked mainly on the management of wild populations and studies of captive $A$. g. clamitans since 1992 (e.g., Mueller et al., 2000; Hirano et al., 2008).

In Rio Grande do Sul, three groups are presently working in primatology. During the last decade, studies on ecological (Silveira \& Codenotti, 2001) and biogeographical (CoDEnotTi et al., 2002) aspects of Alouatta were carried out at Universidade de Passo Fundo. The Laboratório de Primatologia (laboratory of primatology) was established in 2001 at the Pontifícia Universidade Católica do Rio Grande do Sul, focusing mainly on the behavior, cognition abilities, and ecology of different species (e.g., A. g. clamitans, Косн \& BicCAMarques, 2004; A. caraya, Prates \& Bicca-Marques, 2008.)

Finally, the oldest primatological group currently working in Rio Grande do Sul - besides the Projeto Bugio, in all of southern Brazil - is the PMU. The work of this group is not restricted to scientific research, and explores different approaches toward the effective conservation of howlers in Porto Alegre and vicinity, which are presented in the next section.

\section{Programa Macacos Urbanos - a transdisciplinary approach to howler monkey conservation in Porto Alegre and vicinity}

The starting point was the previous knowledge of the existence of howlers somewhere in Porto Alegre, resulting in the development of a survey to investigate where these primates live and how they are distributed in the municipality.

Porto Alegre is the capital of the state of Rio Grande do Sul, founded in the late $18^{\text {th }}$ century and currently among the 10 largest cities of Brazil in terms of population and economy. The human population is estimated at approximately 1.5 million, and this number almost doubles when the neighboring towns are included. Within the municipal boundaries, the human population and economic activities are concentrated in the northern and central most urbanized and commercial areas, but with an increasing trend and pressure to expand to the southern, best-preserved zone (MENEGAT et al., 1998). In this zone, which has historically been devoted to rural activities which helped to preserve some of the largest forest remnants in the city - the largest remaining populations of howlers in Porto Alegre were found by the PMU survey.

This result helped to answer the first questions of the PMU, but raised new scientific questions and brought together requests from local communities, urgent management concerns, and problems with public policies related to biodiversity conservation. These topics were progressively incorporated into the working structure of Macacos Urbanos (Fig. 1). Several professionals and students in biology, veterinary medicine, journalism, geography, and agronomy, from numerous public and

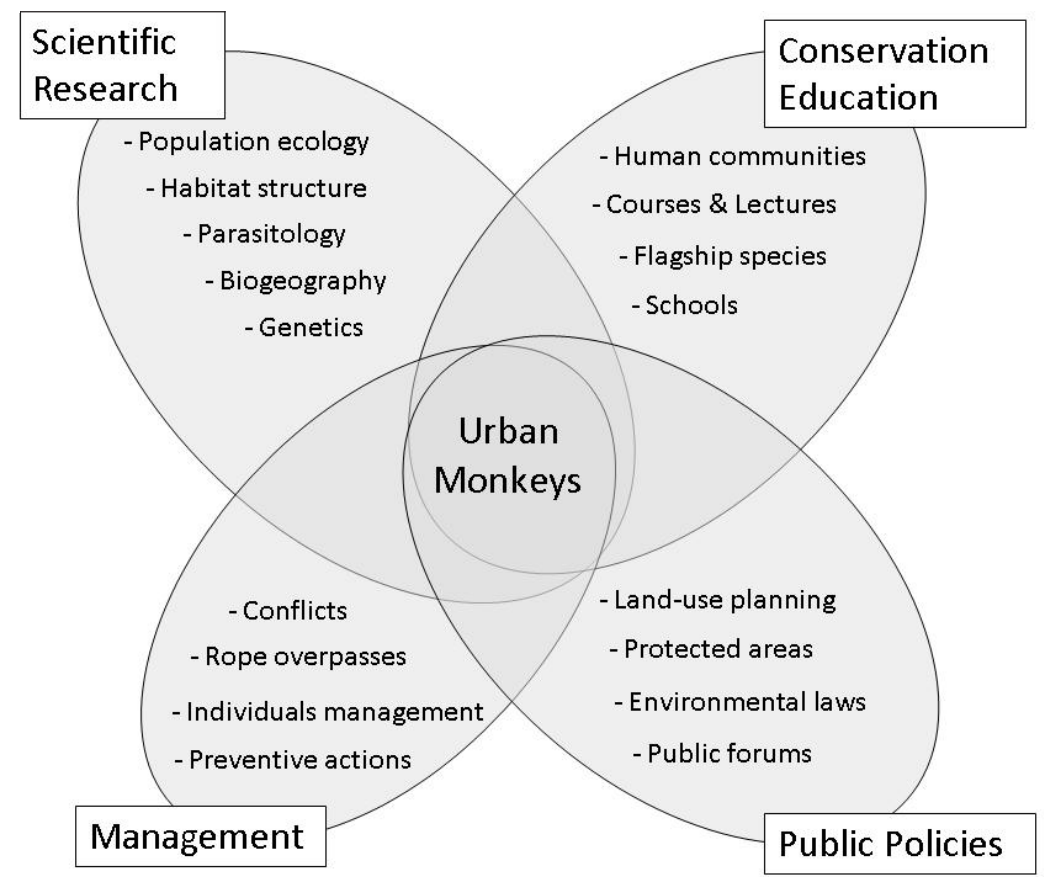

Figure 1. The working structure of the Programa Macacos Urbanos (Urban Monkeys Program), interconnecting scientific research, conservation education, management, and public policy in a transdisciplinary conservationist approach. 
private institutions have joined with the PMU staff in bringing together the diverse knowledge required. In this way, the original Urban Monkeys Project became associated with several other projects, all connected in a transdisciplinary conservationist approach, which originated the Programa Macacos Urbanos (Urban Monkeys Program).

Scientific research. As mentioned, the PMU was initiated by a survey project to answer its first scientific question: "where do howlers live and how are they distributed in Porto Alegre?" The territory of the municipality was divided into three major sections, according to a gradient of increasing urban occupation and decreasing conservation conditions: 1) south, 2) central, and 3) north. The first section included the largest and best-preserved forest fragments in an urban-rural matrix. The second section has a more urbanized matrix, with several small, more-altered forest fragments. The third section encompasses a few remaining forest fragments surrounded by a highly urbanized matrix.
In order to subdivide the sections into sample units, a grid of squares $500 \mathrm{~m}$ x $500 \mathrm{~m}$ was superimposed on the map of soil use and vegetation cover on a scale of 1:50.000. The 25 ha squares totally or partially covered with native forests - which are mainly influenced by the Atlantic forest in a subtropical climate - constituted the sample units. Each unit was visited by two or more researchers, for at least two hours, to check for the occurrence of howlers by either direct sighting of individuals or the presence of feces (Buss, 1996, PRINTEs et al., 2010).

The first section was evaluated between 1994 and 1997, and the presence of howlers was recorded in $54.8 \%$ of the total 197 sample units (Fig. 2; RoMANOWSKI et al., 1998). The distribution of the occurrence areas indicated a metapopulation structure with three major nuclear zones: São Pedro hill, Extrema hill, and Lami district. Interruptions in funding delayed initiation of the survey in the second section, which is now about to be completed, and the analysis of the third section is planned to start soon after.

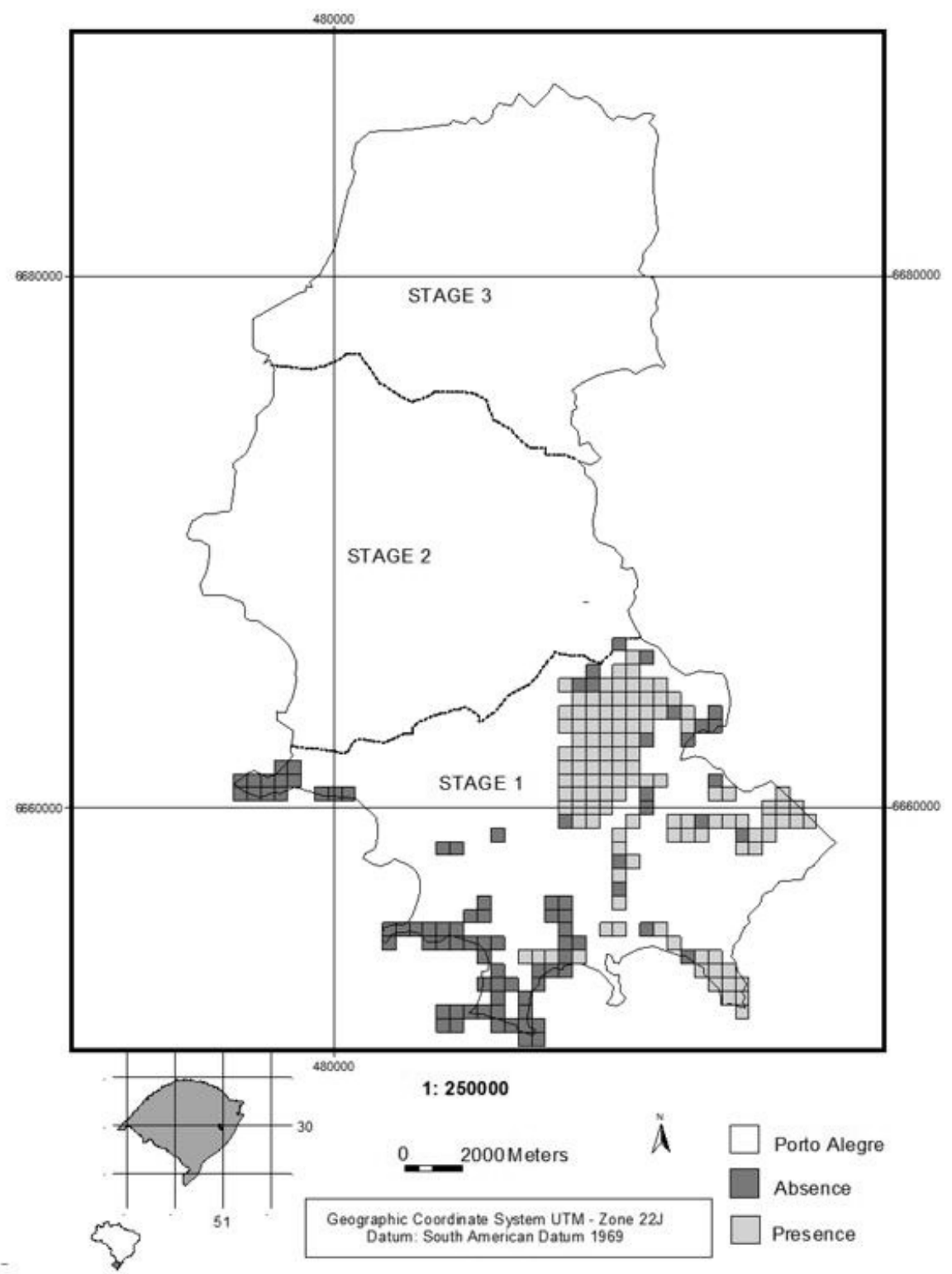

Figure 2. Map of distribution of Alouatta guariba clamitans (Cabrera, 1940) in Porto Alegre, Rio Grande do Sul, Brazil. Modified from PRINTEs et al., 2010. 
The findings in the first section raised several new issues for the conservation of this howler metapopulation, driving research projects on ecology, behavior, and population dynamics. A comparison of the ecology and behavior in winter and summer among howlers inhabiting different types of vegetation indicated the importance of the family Moraceae and some lianas in their diet, and indicated differences among the group on a hillside forest at Extrema hill and the group living in a flatland forest in the Lami district (FialHo, 2000).

Investigating the post-dispersal destination of Diospyros inconstans (Ebenaceae) seeds ingested by howlers at Extrema hill, LIESENFELD (2003) confirmed that these monkeys are efficient and effective dispersers, extending the survival of the seeds even though their germination rate is not improved. Howlers also spread seeds in young secondary forests, confirming their important role in the ecological processes of these forests. Another ecological study, in Parque Estadual de Itapuã (state park) in the neighboring municipality of Viamão and about $20 \mathrm{~km}$ south of Extrema hill, showed a broad relationship between the size of resource patches and the number of individuals in feeding groups - except for Syagrus romanzoffiana (Arecaceae) patches. The number of individuals in feeding groups and the length of their stay in the patches were not significantly related (OLIVEIRA, 2000).

The abundance of howler populations was studied at São Pedro hill and Parque Estadual de Itapuã. For the latter, Buss (2001) estimated the population abundance of howlers in four types of forest formations, and found the highest density in the hygrophilous forest $(0.85 \mathrm{ind} /$ ha), suggested to be related to the structure and floristic composition of this formation (Buss et al., 2009). Extrapolating the average density obtained for all forested areas of the Itapuã park resulted in an estimated total population of about 600 howlers, thus identifying a fourth population nucleus for the region. The population density at São Pedro hill was estimated as $0.99 \mathrm{ind} / \mathrm{ha}$ (Alonso, 2004), allowing us to infer that this area, which contains the largest and best-preserved forest fragment in Porto Alegre (974 ha), supports the largest howler population in the region, almost 1,000 individuals.

Because population parameters are important indicators to show how populations overcome unfavorable conditions and to estimate their long-term prospects for survival, JARDIM (2005) observed 10 groups of howlers in three forest fragments (Parque Estadual de Itapuã, Lami district, and Extrema hill). The average size of the groups was 8.2 individuals, and 31 births were recorded, with a birth rate of 0.6 infants per female. The disappearance of 16 howlers from these groups was attributed to dispersal and/or mortality, and the immigration of one adult female was recorded. The high rate of reproduction, the average size of the group, and important variations in the social composition indicated a trend toward population growth and an intense dynamic in these groups.

The relationship between gastrointestinal parasitism and habitat fragmentation of $A$. g. clamitans was investigated by CABRAL (2007). The incidence of helminth eggs and protozoan oocytes was $19.23 \%$ in samples from the most continuous forest of São Pedro hill, and almost doubled to $38.05 \%$ in samples from the more-fragmented forests of Lami district. As indicated by previous studies (SANTA CRUZ et al., 2000; GILlESPIE \& CHAPMAN, 2006), parasitism increased qualitatively and quantitatively according to the level of habitat fragmentation, and could be a useful indicator of environmental quality to be considered in developing management strategies for the species.

On a broader scale, the southern boundary of the distribution of A. g. clamitans was investigated and extended by $200 \mathrm{~km}$, from the Jacuí river (НIRSCH et al., 1991) to the Camaquã river basin, thus establishing a new southern limit for all Neotropical primates $\left(31^{\circ} 10^{\prime} \mathrm{S}\right.$; PRintes et al., 2001). The seasonal flooding of the Camaquã river, the latitudinal decrease in arboreal species diversity, and the increasing predominance of deciduous trees, together with lower temperatures in winter, were suggested as the key factors defining the southern limits of Recent primates in South America (PRINTES et al., 2001).

The phylogeographic patterns of A. g. clamitans were investigated through mitochondrial sequences of samples from the Porto Alegre region and other Brazilian states. The topology of the resulting phylogenetic trees indicated a recent diversification in this species, and provided preliminary genetic support for the validity of this taxon as an evolutionary significant unit, distinct from A. guariba guariba (Humboldt, 1812) (JERUSALINSKY, 2001).

All these studies have broadened our knowledge about the populations of A. g. clamitans in Porto Alegre and vicinity, and also about the species as a whole, providing essential support for all other conservation efforts of the PMU. Obviously, further studies are required, mainly on the demographic and genetic dynamics of these populations. For example, a group of ongoing investigations is focused on the distribution and persistence of these populations, and whether they are related to the patterns of matrix surrounding the forest fragments. This is necessary information to improve the effectiveness of management measures such as the implementation of landscape corridors for connecting howler habitats.

Conservation education. The inclusion of educational activities in conservation programs facilitates the attainment of conservation goals, and the participation of local communities may be decisive for the success or failure of such programs (JACOBSON et al., 2006). Conservation education programs have a key role in the management of protected areas and conservation of endangered species (Buss et al., 2007). Thus, the use of flagship species - normally charismatic animals - can focus the communities' attention on the importance of biodiversity conservation (SAMMARCo \& PRINTES, 2004; Buss et al., 2007).

The PMU has adopted the flagship-species approach, as a guide for activities, in order to involve communities located close to areas where howlers are present. The aim is to reinforce the importance of conserving howlers and forest remnants.

The first educational campaign of the PMU was initiated in 1995, using the slogan "howlers live in Porto Alegre" to make the occurrence of these primates more widely known in the municipality. An immediate 
consequence of this campaign was the request by schools and communities to host lectures by PMU staff. Later, in 2000, a traveling educational photographic exhibition about the howlers and their habitats was organized and displayed in many public places, including schools. These lectures and the exhibition were the first conservation education activities offered mainly in municipal schools, to share information about howlers.

Several short courses during academic and scientific events were organized for the specialized public, as a way to disseminate knowledge of conservation biology and to share the PMU's practical experiences. In addition, in 2004 a course about fauna management was offered to park rangers and soldiers of the military police environmental detachment in Rio Grande do Sul.

In 2007, the first conservation biology course was offered, based on the study cases of the PMU. This course was offered three times, to about 75 students and professionals with different backgrounds in environmental issues, who gained a wider view and improved qualifications to deal with biodiversity conservation challenges.

During 2000, a project was carried out using the concept of a core school curriculum in environmental education. This project was developed in a school located at the base of São Pedro hill, where many conflicts involving the local community and howlers had occurred, such as hunting and attacks on the howlers. The main objective of this project was to involve the whole school community in howler conservation, including training teachers as multipliers in environmental education. Some important results were obtained, such as the inclusion of the environmental theme in the lesson plans for all subjects taught (SAMMARCO \& PRINTES, 2004).

A conservation education project in the Lomba do Pinheiro schools was carried out from 2005 to 2009, during the survey of howlers in the second section of the municipality. A small number of howlers were recorded in the few forest remnants in this neighborhood, which are severely menaced by unplanned urbanization, making the extinction of this population imminent. This project involved 116 student classes from local schools in different educational activities, aiming to influence the local community to increase the chances that this howler population will persist (TEIXEIRA et al., in press.).

All these conservation education efforts demonstrated the need to involve local communities in howler conservation, in addition to the importance of making the scientific community more aware of practical conservation issues. Since the PMU staff began interacting with local communities, their interest in howlers clearly increased, strengthening the effectiveness of this species as a flagship to influence biodiversity conservation in the region.

Management. Conflicts between humans and nonhuman primates close to urban centers tend to increase (Melo et al., 2009) because of unplanned urban expansion and the cities' dependence on local ecosystems, leading to habitat degradation and greater exposure of wild primates to a diverse array of threats (FOLKE et al., 1997). Many birds, reptiles, and mammals can survive in urban and suburban areas (DiтcнкоғF et al., 2006) due to their capacity to cope in highly fragmented landscapes, and howler monkeys also seem to have this ability (BICCAMARques, 2003). However, proximity to humans may generate repeated conflicts, necessitating direct management of individuals and populations (HoRwICH, 1998; Hill, 2000; LoudON et al., 2006).

There is no clear consensus about the best strategy to manage fauna in these situations (e.g., AGORAMOORTHY, 1995; Magnusson, 1995). Efforts to return a few individuals of non-threatened species to the wild are not usually considered conservationist measures, nor are measures focused on individual members of endangered species (SOORAE \& BAKER, 2002). Nevertheless, because howlers are considered locally and regionally threatened and conflicts with humans in Porto Alegre and vicinity are frequent (PRINTES, 1999; PRINTES et al., 2010; LOKSCHIN et al., 2007), the PMU considered that it was necessary to manage individual howler monkeys.

Since 1999, the PMU has collected systematic data about areas of conflict and the causes and consequences of direct threats to howlers. Until 2008, the group participated in different stages of the management of 49 howler individuals in Porto Alegre and vicinity (CABRAL et al., in press). More than $55 \%$ of these cases (27) were caused by electrocution on power lines, finds of weak or ill individuals, and attacks by domestic dogs. Other frequent causes were highway accidents, mistreatment, and individuals kept as pets, for a total of 15 cases $(30.6 \%)$. Although the average of approximately five cases per year is clearly an underestimate of the real number of individuals affected by these impacts in Porto Alegre and vicinity, the maintenance of this database was crucial to evaluate the magnitude and location of these threats.

Systematic data collection was also decisive in identifying: a) professional and institutional responsibilities in different management cases; b) some failures in technical knowledge of management procedures; and c) the need to standardize data collection, with the adoption of a single management protocol used by all institutions involved. As a consequence of these experiences, a standardized management protocol to deal with emergencies involving howlers and a decisionmaking procedure were developed and applied by the PMU. The improvement in information-sharing and increased cooperation among the different entities involved with wild fauna were essential to modify practices for urgent management of howlers, with faster and better-coordinated actions. Furthermore, the interaction with local communities, through educational or research activities, helped to overcome the difficulties in obtaining information about emergency cases.

The disposition of individual monkeys is now decided on the basis of some elementary information. Monkeys are kept permanently in captivity if they: 1) have irreversible injuries, such as amputation, or critical limitations caused by conflicts; 2) are infants that would need parental care to survive; or 3) have an unknown origin. The basic conditions required to release individuals back to nature are: 1) a positive veterinary evaluation; 2) if they are sufficiently mature to survive independently; and 3) if the exact place of origin is known. Once the decision is made to return an individual to the wild, the 
release site is selected according to the following criteria: 1) natural occurrence of howlers; 2) proximity to the animal's place of origin, attempting to minimize alterations in the social, genetic, and health structure of populations; and 3) availability of adequate habitat, mainly considering the fragment size, connectivity, preservation level, and surrounding matrix (CABRAL et al., in press).

These experiences provided substantial support for appropriate management of howlers in the region and for setting priorities for their conservation strategies. The level of management success proved to depend not only on direct manipulative actions, but also - and fundamentally - on preventive strategies, including the improvement of social sensitivity to environmental issues and influence on public policies. An example of such preventive actions was the coating of power lines and the installation of elevated rope bridges to prevent electrocutions and road mortality of howlers in the Lami district (LoKSCHIN et al., 2007). Unjustified trapping of animals makes it essential to reinforce the role of conservationist education programs as a preventive management strategy. Participation in and promotion of participatory forums are central to improve interactions among institutions and to overcome inadequacies in public policies for wildlife conservation in urban areas. This process has progressively improved the management and even prevented emergency cases with howlers in Porto Alegre and vicinity.

Public policies. The results of scientific research, educational activities, and management actions of the PMU are often applied to influence policy, with the primary aim of motivating public and private initiatives towards the conservation of forest remnants in Porto Alegre. Field data are frequently presented to different stakeholders in order to promote howler conservation, by influencing management decisions, the creation and expansion of protected areas, and the maintenance or restoration of connectivity between forest fragments.

Different approaches have included: 1) participation in public forums focused on land-use planning; 2) direct contact with landowners to educate them about the importance of their land for the survival of howlers; 3 ) persuading politicians to pass and improve laws to reconcile human occupation patterns with the conservation of howler habitat; 4) participation in advisory councils for protected areas where howlers occur, to assist with management decisions and to promote strategies such as corridors; and 5) as extreme actions, to promote juridical processes based on the principles of collective and public interests, to enhance respect for Brazilian environmental laws (LoKsCHIN et al., 2007).

These different strategies are employed depending on the situation at hand, and the work on each one usually takes more than a year, requiring continuous monitoring. Crucial to their success is constant participation in many meetings and forums involving stakeholders with different, and often divergent, views, including environmentalists, farmers, fishermen, businessmen, engineers, politicians, etc. In these forums, the central focus of the PMU is the use of howlers as a flagship species to promote the conservation of biodiversity in Porto Alegre, raising practical issues such as the contributions of the rural areas to the dynamics and economy of the city, the importance of the forest remnants in maintaining climate equilibrium, and the role of streams in maintaining quality of life for the human residents.

Some major results of this approach were the alteration of the municipal master plan, the approval of a new regulation for taxes in rural and forested areas, the creation and enlargement of protected areas, and the coating of electric power lines in risk zones for howlers. The original proposal for the $2^{\text {nd }}$ municipal master plan of Porto Alegre included paving a road situated between the two largest forest fragments of the municipality, São Pedro and Extrema hills. For two years, PMU personnel attended planning meetings to present the results of its howler survey, defending the need to maintain connectivity between these populations. Fortunately, the effort was successful and the planned asphalt road was relocated to a more appropriate area, thus maintaining the possibility of dispersal between these populations (Buss et al., 2008).

Another successful strategy began in 1999, by documenting incidents of electrocution from power lines involving howlers and other animals (PRINTES, 1999). After two years of legal proceedings, the court finally ordered the energy company of Rio Grande do Sul to coat and insulate power lines in areas where howlers are at risk of electrocution, as indicated by the PMU, mainly in the Lami district (LoKSCHIN et al., 2007). Electrical hazards are still present in this and other neighborhoods, and constant monitoring is needed to prevent accidents and to appropriately manage the affected individuals.

Besides preventing the isolation of populations or direct hazard to individuals, assuring habitat protection is one of the main strategies to conserve species (TABARELLI \& GASCON, 2005). In order to preserve suitable habitats for howler monkeys, the PMU participated for six years in policy forums defending the creation of a new rule for taxation in rural and forested areas of Porto Alegre. This culminated in the implementation of the municipal complementary law no. 482, in 2002, which allows owners of forested areas to apply for exemption from property taxes.

Simultaneously with this strategy, the PMU worked to ensure the conservation of howler habitats through participation in the planning and creation of public and private protected areas. About 320 ha are already protected, and a further 587 ha are in negotiation or in the process of transfer.

In this working front, new demands are constantly arising, and ongoing activities require the dedication of large amounts of time. A permanent and engaged participation in the long-term processes, until their conclusion, is indispensable to gain successes in this conservation strategy. This engagement is a key way to put into practice the results of scientific research, using the information to develop effective measures for the conservation of howlers and their habitats.

\section{Future prospects}

It is expected that in the next few years, new primatological investigations will fill at least part of the 
present gaps in knowledge for southern Brazil. Nevertheless, it is also necessary to deal with the conservation challenges that are increasingly affecting primates in this region. Currently, all the howler populations are living in forest fragments, a few of them large (frequently the protected areas), some medium, and several small. It is widely known that fragmented populations are more exposed to demographic, genetic, and environmental stochastic factors, which may synergistically interact, accentuating population declines and even causing local extinctions (GILPIN \& Soulé, 1986). One necessary action to deal with this problem is to evaluate the effectiveness of the protected area system in maintaining secure and viable populations.

Because habitat fragmentation is a major trend and problem - for primate populations in this region, the feasibility and efficacy of different types of corridors should be tested. It is also important to investigate the role that different matrices might play in the dispersal (or isolation) of individuals and populations and their persistence. For these fragmented populations, the number of natural predators has decreased, so it is also essential to examine the influence of parasitism on their regulation.

Over the long term, primatologists in southern Brazil must take into account the possible phytogeographic alterations related to climate change and the consequences for the species' habitats. Hence, the immediate implementation of long-term monitoring programs, inside and outside protected areas, should generate appropriate information to guide management and conservation policies.

On the other hand, budgetary and other limitations on the regional institutions constrain the local absorption of trained professionals. Hence, it is desirable and necessary that new positions be created by universities and public agencies to employ locally trained primatologists, and, consequently, to maintain the quality of environmental management and scientific research focusing on regional primate conservation (Melo et al., 2009).

The establishment of a harmonious, or at least respectful, coexistence of human and non-human primates is a major issue for primate conservation worldwide (BURTON \& CARROLL, 2005). It is no different in southern Brazil, where conflicts involving human communities and wild primates are increasingly frequent, especially in the surroundings of the largest urban centers. Human proximity associated with decrease in fragment size and resource availability may increase primate stress levels, with their negative impacts on social organization and vulnerability to disease. The problems dealt with by the PMU, such as electrocutions, roadkills and overparasitism (PRINTES, 1999; LOKSCHIN et al., 2007), will probably become more common, accompanying the progressive urban expansion, and their impacts should be monitored.

What posture should primatologists assume to face these challenges? We believe that, in addition to a massive effort in basic and applied research, it is crucial to work collectively (e.g., working groups, inter-institutional cooperation) and to develop the flexibility to act in diversified and interrelated working fronts. Conservation education projects as part of research programs, for example, have proven effective in opening dialogues and involving local communities in a participatory conservation process (PADUA et al., 2008). Furthermore, the closer cooperation of primatologists with decisionmakers to create, improve, or block public policies, or even assume strategic positions in different levels of government, will certainly strengthen the strategies and make a difference for primate conservation.

Acknowledgments. We thank all the members of the Núcleo de Extensão Macacos Urbanos, especially Dr. Helena Romanowski (UFRGS) for her support for the group since its beginning. For their cooperation in management and education activities, we thank: Núcleo de Fauna IBAMA/RS, Centro Estadual de Vigilância em Saúde/RS, Dr. Gleide Marsicano, Prefeitura Municipal de Porto Alegre, Fundação Zoobotânica do Rio Grande do Sul, $1^{\circ}$ Comando Ambiental da Brigada Militar, Instituto Popular de Arte-Educação da Lomba do Pinheiro, and school communities. Several professionals and institutions have contributed often and in many ways to our scientific research, and we recognize their support: Dr. Luis Flamarion Barbosa de Oliveira (Museu Nacional/ UFRJ), Dr. Anthony Rylands (Conservation International), Dr. Luciana Oklander (CONICET), Dr. Sandro Bonatto (PUCRS), Dr Thales de Freitas (UFRGS), Dr. Eleonore Setz (UNICAMP), Dr. Andreas Kindel (UFRGS), Dr. Fernando Becker (UFRGS), Dr. Stephen Ferrari (UFS), Dr. Fabiano Melo (UFG), M.Sc. Heloisa Junqueira (UFRGS), WWF, FAPESP, Margot Marsh Foundation, Fundação O Boticário de Proteção à Natureza, and IdeaWild.

\section{REFERENCES}

Agoramoorthy, G. 1995. Red howling monkey (Alouatta seniculus) reintroduction in a gallery forest of Hato Flores Moradas, Venezuela. Neotropical Primates 3(1):9-10.

Aguiar, L. M.; Mellek, D. M.; Abreu, K. C.; Boscarato, T. G.; Bernardi, I. P.; Miranda, J. M. D. \& Passos, F. C. 2007. Sympatry between Alouatta caraya and Alouatta clamitans and the rediscovery of free-ranging potential hybrids in southern Brazil. Primates 48(3):245-248.

Aguiar, L. M.; Pie, M. R. \& Passos, F. C. 2008. Wild mixed groups of howler species (Alouatta caraya and Alouatta clamitans) and new evidence for their hybridization. Primates 49(2): 149-152.

Alonso, A. C. 2004 . Estimativa de densidade de bugio-ruivo (Alouatta guariba clamitans Cabrera, 1940) na Reserva Ecológica Econsciência - Morro São Pedro, Porto Alegre, RS, Brasil. 20p. Dissertação de Bacharelado, ênfase ambiental, Universidade Federal do Rio Grande do Sul, Porto Alegre. (Unpublished)

Bicca-Marques, J. C. 1990. A new southern limit for the distribution of Alouatta caraya in Rio Grande do Sul State, Brasil. Primates 31(3):449-451.

1992. Drinking Behavior in the Black Howler Monkey, Alouatta caraya. Folia Primatologica 58:107-111.

2003. How do howler monkeys cope with habitat fragmentation? In: Marsh, L. K. ed. Primates in Fragments: ecology and conservation. New York, Kluwer Academic. p.283-303.

Bicca-Marques, J. C. \& Calegaro-Marques, C. 1993. Feeding Postures in the Black Howler Monkey, Alouatta caraya. Folia Primatologica 60:169-172.

Bicca-Marques, J. C.; Prates, H. M.; de Aguiar F. R. C. \& Jones, C. B. 2008. Survey of Alouatta caraya, the black-and-gold howler monkey, and Alouatta guariba clamitans, the brown howler monkey, in a contact zone, State of Rio Grande do Sul, Brazil: evidence of hybridization. Primates 49(4):246-252.

BrasiL. 2003. Instrução Normativa Ministério do Meio Ambiente $\mathrm{N}^{\circ}$ 03, de 27 de maio de 2003: Lista Oficial das Espécies da Fauna Brasileira Ameaçadas de Extinção. Ministério do Meio Ambiente, Brasília, Brasil. Diário Oficial da União, v. 101, p.88-97, Seção 1 .

Burton, F. \& Carroll, A. 2005. By-product mutualism: conservation implications amongst monkeys, figs, humans, 
and their domesticants in Honduras. In: Paterson, J. D. \& WAllis, J. eds. Commensalism and conflict: the humanprimate interface. Oklahoma, American Society of Primatologists. p.24-39.

Buss, G. 1996. Urban Monkeys - Alouatta fusca in the municipality of Porto Alegre. Neotropical Primates 4(2):61, 62.

. 2001. Densidade populacional do bugio-ruivo nas formações florestais do morro do Campista, Parque Estadual de Itapuã. 90p. Dissertação de Mestrado. Universidade Federal do Rio Grande do Sul, Porto Alegre. (Unpublished)

Buss, G.; Leite, S. L. C. \& Brutto, L. F. G. 2008. O novo plano diretor e a conservação do bugio-ruivo (Alouatta guariba clamitans Cabrera, 1940) no município de Porto Alegre, RS. In: Ferrari, S. F. \& Rímoli, J. eds. A Primatologia no Brasil - 9. Aracaju, Sociedade Brasileira de Primatologia, Biologia Geral e Experimental - UFS. p.169-178.

Buss, G.; Leite, S. L. C. \& Romanowski, H. P. 2009. Formações florestais do Parque Estadual de Itapuã, Rio Grande do Sul: caracterização do hábitat do bugio-ruivo (Alouatta clamitans, Cabrera 1940). Revista Brasileira de Biociências 7(3):291-304.

Buss, G.; Lokschin, L. X.; Setubal, R. B. \& Teixeira, F. Z. 2007. A abordagem de espécie-bandeira na Educação Ambiental: estudo de caso do bugio-ruivo (Alouatta guariba) e o Programa Macacos Urbanos. In: Gorczevski, C. org. Direitos Humanos, Educação e Meio Ambiente. Porto Alegre, Evangraf. p.165-185.

Cabral, J. N. H. 2007. Diagnóstico e monitoramento ambiental - estudo de caso do bairro Lami, Porto Alegre, RS baseado nas experiências do Programa Macacos Urbanos - pesquisa e conservação de primatas no Rio Grande do Sul. 102p. Trabalho de conclusão, Especialização em Análises Clínicas Veterinárias, Universidade Federal do Rio Grande do Sul, Porto Alegre. (Unpublished)

Cabral, J. N. H.; Rossato, R. S.; Michel, T.; Buss, G.; Lokschin, L. X.; Jardim, M. M. DE A. \& Alonso, A. C. In press. Manejo emergencial de bugios-ruivos nos municípios de Porto Alegre e Viamão, RS - o desafio da conservação de primatas em áreas urbanas. In: A Primatologia no Brasil v.11.

Calegaro-Marques, C. \& Bicca-Marques, J. C. 1993. Allomaternal care in the black howler monkey (Alouatta caraya). Folia Primatologica 61(2): 104-109.

Chiarello, A. 2003. Primates of the Brazilian Atlantic forest: The influence of forest fragmentation on survival. In: MARsh, L. K. ed. Primates in Fragments: ecology and conservation. New York, Kluwer Academic. p.99-121.

Codenotti, T. L.; Silva, V. M.; Albuquerque, V. J.; Camargo, E. V. \& Silveira, R. M. M. 2002. Distribuição e situação atual de conservação de Alouatta caraya (Humboldt, 1812) no Rio Grande do Sul, Brasil. Neotropical Primates 10(3):132-140.

Ditchkoff, S. S.; SAAfeld, S. T. \& Gibson, C. J. 2006. Animal behavior in urban ecosystems: modification due to human induced stress. Urban Ecosystems 9:5-12.

Fialho, M. de S. 2000. Ecologia do bugio ruivo (Alouatta fusca) em floresta de encosta e de restinga no sul do Brasil. 171p. Dissertação de Mestrado. Universidade Estadual de Campinas, Campinas. (Unpublished)

Folke, C.; Jansson, A.; Larsson, J. \& Constanza, R. 1997. Ecosystem appropriation by cities. Ambio 26(3):167-172.

Fortes, V. B. \& Bicca-Marques, J. C. 2008. Abnormal Pelage Color in an Isolated Population of Alouatta guariba clamitans Cabrera, 1940 in South Brazil. International Journal of Primatology 29:717-722.

Garcia, J. L.; Svoboda, W. K.; Chryssafidis, A. L.; Malanski, L. DE S.; Shiozawa, M. M.; Aguiar, L. De M.; Teixeira, G. M.; Ludwig, G.; Da Silva, L. R.; Hilst, C. \& Navarro, I. T. 2005. Seroepidemiological survey for toxoplasmosis in wild New World Monkeys (Cebus spp. and Alouatta caraya) at the Paraná River basin, Paraná State, Brazil. Veterinary Parasitology 133(4):307-311.

Gillespie, T. R. \& Chapman, C. A. 2006. Prediction of parasite infection dynamics in primate metapopulations based on attributes of forest fragmentation. Conservation Biology 20:441-448.

Gilpin, M. E. \& Soulé, M. E. 1986. Minimum viable populations: process of species extinction. In: Soulé, M. E. ed. Conservation
Biology. The Science of Scarcity and Diversity. Sunderland, Sinauer Associates. p.19-34.

Hill, C. M. 2000. Conflict of interest between people and baboons: crop raiding in Uganda. International Journal of Primatology 21(2):299-315.

Hirano, Z. M. B.; Correa, I. C. \& Oliveira, D. A. G. 2008. Contexts of rubbing behavior in Alouatta guariba clamitans: a scent-marking role? American Journal of Primatology 70(6):575-583.

Hirsch, A.; Landau, E. C.; Tedeschi, A. C. De M. \& Meneguetti, J. O. 1991. Estudo comparativo das espécies do gênero Alouatta Lacèpéde, 1799 (Plathyrrhini, Atellidae) e sua distribuição geográfica na América do Sul. In: Rylands, A. B. \& Bernardes, A. T. eds. A Primatologia no Brasil - 3. Belo Horizonte, Sociedade Brasileira de Primatologia, Fundação Biodiversitas. p.239-262.

HoRwich, R. H. 1998. Effective solutions for howler conservation. International Journal of Primatology 19(3):579-598.

IUCN. 2001. IUCN Categories and Criteria: Version 3.1. IUCN Species Survival Commission. Gland, Switzerland and Cambridge UK, IUCN. 30p.

IUCN. 2010. IUCN Red List of Threatened Species. Version 2010.2. Available at: 〈www.iucnredlist.org〉. Accessed on: 08.15 .2010

Jacobson, S. K.; McDuff, M. D. \& Monroe, M. C. 2006. Conservation Education and Outreach Techniques. Oxford, Oxford University. 480p.

JARDIM, M. M. DE A. 2005. Ecologia populacional do bugioruivo nos municípios de Porto Alegre e Viamão, RS, Brasil. 114p. Tese de Doutorado. Universidade Estadual de Campinas, Campinas. (Unpublished)

Jardim, M. M. DE A. \& Oliveira, L. F. B. 2000. Aspectos ecológicos e do comportamento de Alouatta fusca (Geoffroy, 1812) na Estação Ecológica de Aracuri, RS, Brasil. In: Alonso, C. \& Langggth, A. eds. A Primatologia no Brasil - 7. João Pessoa, Editora Universitária. p.151-169.

Jerusalinsky, L. 2001. Diversidade em seqüências mitocondriais do bugio-ruivo (Alouatta guariba): implicações para a história evolutiva e a conservação da espécie. 80p. Dissertação de Mestrado. Universidade Federal do Rio Grande do Sul, Porto Alegre. (Unpublished)

Косн, F. \& Bicca-Marques, J. C. 2004. Substrate manipulation by Alouatta guariba clamitans in solving a locomotor problem. Neotropical Primates 12(3):138-139.

Koehler, A.; Pereira, L. C. M. \& Nicola, P. A. 2002. New locality for the wooly spider monkey Brachyteles arachnoides (E.Geoffroy, 1806) in Paraná state and the urgency of strategies for conservation. Estudos de Biologia 24(49):25-28.

Koenler, A. B.; Pereira, L. C. M.; Nicola, P. A.; Ângelo, A. C. \& Weber, K. S. 2005. The southern Muriqui, Brachyteles arachnoides, in the state of Paraná, current distribution, ecology and the basis for a conservation strategy. Neotropical Primates 13:67-72.

Liesenfeld, M. V. A. 2003. Destino pós dispersão de sementes de caquizinho-do-mato (Diospyrus inconstans) ingeridas pelo bugio-ruivo (Alouatta guariba clamitans) em uma floresta subtropical no sul do Brasil. 80p. Dissertação de Mestrado. Universidade Estadual de Campinas, Campinas. (Unpublished)

Lokschin, L. X.; Printes, R. C.; Cabral, J. N. H. \& Buss, G. 2007. Power lines and Howler Monkey conservation in Porto Alegre, Rio Grande do Sul, Brazil. Neotropical Primates 14(2):76-79.

Loudon J. E.; SAuther, M. L.; Fish, K. D.; Hunter-Ishikawa, M. \& IвRAHim, Y. J. 2006. One reserve three primates: applying a holistic approach to understand the interconnections among ring-tailed lemurs (Lemur catta), Verreaux's sifaka (Propitecus verreauxi), and humans (Homo sapiens) at Beza Mahafaly Special Reserve, Madagascar. Ecological and Environmental Anthropology 2(2):54-74.

Machado, A. B. M.; Martins, C. S. \& Drummond, G. M. 2005 Lista da fauna brasileira ameaçada de extinção: incluindo as espécies quase ameaçadas e deficientes em dados. Belo Horizonte, Fundação Biodiversitas. 160p.

Magnusson, W. E. 1995. Reintrodução: uma ferramenta conservacionista ou brinquedo perigoso? Neotropical Primates 3(3):82-84.

Melo, F. R.; Buss, G.; Printes, R. C.; Jardim, M. M. A.; Silva Junior, 
J. C.; Oliveira, M. M.; Rimoli, J.; Talebi, M. G. \& Hirano, Z. B. 2009. Primatologia no Brasil: 15 anos de retrospecto e perspectivas futuras. In: DA RochA, R. M. \& BOEger, W. A Estado da arte e perspectivas para a Zoologia no Brasil. Curitiba, UFPR, p.249-270.

Menegat, R.; Porto, M. L.; Carraro, C. C. \& Fernandes, L. A. D. 1998. Atlas Ambiental de Porto Alegre. Porto Alegre, UFRGS, INPE \& PMPA. 228p.

Miranda, J. M. D.; Aguiar, L. M.; Ludwig, G.; Moro-Rios, R. F. \& Passos, F. C. 2005. The first seven months of an infant of Alouatta guariba (Humboldt) (Primates, Atelidae): interactions and the development of behavioral patterns. Revista Brasileira de Zoologia 22:1191-1195.

Miranda, J. M. D.; Itiberê, P. B.; Moro-Rios, R. F.; Aguiar, L. M.; LudwiG, G. \& Passos, F. C. 2004. Social structure of Alouatta guariba clamitans: a group with a dominant female. Neotropical Primates 12(3):135-138.

Mueller, G. C. K.; Krambeck, A.; Hirano, Z. M. B. \& Silva Filho, H. H. 2000. Levantamento preliminar de endoparasitas do tubo digestivo de bugios Alouatta guariba clamitans. Neotropical Primates 8(3): 107-108.

Oliveira, E. G. R. 2000. Tamanho de árvore e uso de recurso alimentar em um bando de bugios-ruivos (Alouatta fusca, Geoffroy, 1812) no Parque Estadual de Itapuã, Viamão, RS, Brasil. 20 p. Dissertação de Bacharelado. Universidade Federal do Rio Grande do Sul, Porto Alegre. (Unpublished)

Padua, S. M.; Dietz, L. A.; Souza, M. das G. De \& Santos, G. R. dos. 2008. Educação Conservacionista In Situ e os Micos-Leões. In: Kleiman, D. G.; Rylands, A. B.; Maury, C. \& Alvarez, C. A B. orgs. Micos leões: biologia e conservação. Brasília, Cidade Gráfica e Editora. p.418-445.

Padua, C. V. \& Prado, F. 1996. Notes on the natural history of the black-faced lion tamarin Leontopithecus caissara. Journal of Wildlife Preservation 32:123-125.

Paraná. 2004. Decreto Estadual $n^{\circ} 3.148$, de 15 de junho de 2004. Estabelece a Política Estadual de Proteção à Fauna Nativa. Diário Oficial do Estado do Paraná, n.6750, p.35, 15 jun de 2004 .

Passos, F. C.; Miranda, J. M. D.; Aguiar, L. DE M.; Ludwig, G.; Bernardi, I. P. \& Moro-Rios, R. F. 2007. Distribuição e ocorrência de primatas no estado do Paraná, Brasil. In: BiccAMarques, J. C. ed. A Primatologia no Brasil 10. Porto Alegre, EDIPUCRS. p.119-149.

Peres, C. A. \& Janson, C. H. 1999. Species coexistence, distribution, and environmental determinants of neotropical primate richness: a community-level zoogeographic analysis. In: Fleagle, J. G.; Janson, C. H. \& Reed, K. E. eds. Primate Communities. Cambridge, Cambridge University. p.55-74.

Prado, F. \& Valladares-Padua, C. 2004. Ecologia alimentar de um grupo de mico-leão-da-cara-preta, Leontopithecus caissara (Primates, Callitrichidae), no Parque Nacional de Superagui, Guaraqueçaba - PR, Brasil. In: Mendes, S. L. \& Chiarello, A. G. orgs. A Primatologia no Brasil 8. Vitória, IPEMA/SBPr. p.145-154.

Prates, H. M. \& Bicca-Marques, J. C. 2008. Age-sex analysis of activity budget, diet, and positional behavior in Alouatta caraya in an orchard forest. International Journal of Primatology 29:703-715.

Prates, J. C.; Gayer, S. M. P.; Kunz JR., L. F. \& Buss, G. 1990a. Feeding habits of the brown howler monkey Alouatta fusca clamitans (Cabrera, 1940) (Cebidae, Alouattinae) in the Itapuã State Park: A preliminary report. Acta Biologica Leopoldensia 12:175-188.

Prates, J. C.; Kunz Jr., L. F. \& Buss, G. 1990b. Comportamento postural e locomotor de Alouatta fusca clamitans (Cabrera, 1940) em Floresta Subtropical (Primates, Cebidae). Acta Biologica Leopoldensia 12:189-200.

Prates, J. C.; Kunz JR., L. F.; Rosa, A. O.; Jardim, M. M. A. \& Silva, C. R. C. 1994. Primatas do Rio Grande do Sul: ocorrência em unidades de conservação. In: Yамамото, M. E. \& Sousa, M. M. C. eds. A Primatologia no Brasil - 4. Natal, Sociedade Brasileira de Primatologia. p.183-194.

Printes, R. C. 1999. The Lami Biological Reserve, Rio Grande do Sul, Brazil, and the danger of power lines to howlers in urban reserves. Neotropical Primates 7(4):135, 136.

Printes, R. C.; Liesenfeld, M. V. A. \& Jerusalinsky, L. 2001. Alouatta guariba clamitans (Cabrera, 1940): a new southern limit for the species and for Neotropical Primates. Neotropical Primates 9(3):118-121.

Printes, R. C.; Buss, G.; Jardim, M. M. de A.; Fialho, M. de S.; Dornelles, S. da S.; Perotto, M.; Brutto, L. F. G.; Girardi, E.; JeRUSAlinsKy, L.; LiESENFELD, M. V.; LOKSChIN, L. X. \& RoMANOWSKY, H. P. 2010. The Urban Monkeys Program: a survey of Alouatta clamitans in the south of Porto Alegre and its influence on land use policy between 1997 and 2007. Primate Conservation 25 (Published electronically prior to print publication: <http:// www.primate-sg.org/PC25.htm>).

Ribeiro, S. \& Bicca-Marques, J. C. 2005. Características da paisagem e sua relação com a ocorrência de bugios-ruivos (Alouatta guariba clamitans, Cabrera, 1940; Primates, Atelidae) em fragmentos florestais no Vale do Taquari, RS. Natureza e Conservação 3(2):65-78.

Rio Grande do Sul. 2002. Decreto Estadual n 41.672, de 11 de junho de 2002. Declara as espécies da fauna silvestre ameaçadas de extinção no Estado do Rio Grande do Sul. Diário Oficial do Estado do Rio Grande do Sul, Porto Alegre, v.110, p.14, 12 jun. 2002.

Romanowski, H. P.; Dornelles, S. S.; Buss, G.; Brutto, L. F. G.; Jardim, M. M. S.; Printes, R. C. \& Fialho, M. S. 1998. Bugioruivo: o ronco ameaçado. In: Menegat, R.; Porto, M. L.; Carraro, C. C. \& Fernandes, L. A. D. ed. Atlas Ambiental de Porto Alegre. Porto Alegre, UFRGS/PMPA/INPE. p.62, 63.

Sammarco, Y. M. \& Printes, R. C. 2004. Desenvolvimento de uma escola-pólo em educação ambiental: a conservação do bugio e seu hábitat. In: Kindel, E. Educação Ambiental: vários olhares e várias práticas. Porto Alegre, Mediação. p.71-78.

Santa Cruz, A. C. M.; Borda, J. T.; Patino, E. M.; Gómez, L. \& Zunino, G. E. 2000. Habitat fragmentation and parasitism in howler monkeys (Alouatta caraya). Neotropical Primates 8(4): $146-148$.

Silva, V. M. \& Codenotti, T. L. 2007. Mapeamento das áreas de ocorrência de Alouatta caraya em fragmentos florestais de Tupanciretã, Rio Grande do Sul. In: Bicca-Marques, J. C. ed. A Primatologia no Brasil 10. Porto Alegre, Sociedade Brasileira de Primatologia, EDIPUCRS. p.181-191.

Silveira, R. M. M. \& CodenotTI, T. L. 2001. Interações sociais e dieta do bugio-ruivo, Alouatta guariba clamitans, no Parque Estadual de Itapuã, RS, Brasil. Neotropical Primates 9(1):15-19.

SOORAE, P. S. \& BAKer, L. R. 2002. Re-introduction news: special primate issue, newsletter of the IUCN/SSC Reintroduction specialist group. Abu Dhabi, UAE. $\mathrm{n}^{\circ} 21,60 \mathrm{p}$.

TABARELli, M. \& GASCON, C. 2005. Lessons from fragmentation research: improving management and policy guidelines for biodiversity conservation. Conservation Biology 19(3):734-739.

Teixeira, F. Z.; Nascimento, L. S.; Setubal, R. B.; Lopes, M. S. \& JunQueIRA, H. In press. Educação para conservação do bugioruivo em áreas urbanas, Porto Alegre, RS. In: A Primatologia no Brasil v. 11 